J. Clin. Chem. Clin. Biochem.

Vol. 15, 1977, pp. 669-677

\title{
Development of a Radioimmunoassay for Cyclic Somatostatin: Antibody Production, Comparative Radioiodination, and Dose-Response Curve
}

\author{
By F. Diel, Elisabeth Schneider and H. J. Quabbe
}

Department of Medicine, Section of Endocrinology, Klinikum Steglitz, Free University Berlin

(Received March 25, 1977)

Summary: A radioimmunoassay for the measurement of cyclic somatostatin is described. Synthetic somatostatin was conjugated with bovine serum albumin or human serum $\alpha$-globulin using glutaraldehyde as the coupling reagent. Antisera were raised in rabbits injected with the hapten-bovine serum albumin'-, or with the hapten-human serum $\alpha$-globulinconjugate.

Since somatostatin lacks a tyrosine residue that can be readily iodinated, three different radiolabeling procedures for synthetic cyclic $\mathrm{Tyr}^{1}$-somatostatin were compared with each other. In addition, cyclic somatostatin was radiolabeled with the Bolton-Hunter reagent. The radiolabeled antigens were purified by G-25 Sephadex adsorption chromatography and thus separated from unreacted components. Maximal yields were achieved when Tyr $^{1}$-somatostatin was iodinated with chloramine-T the largest immunochemical reactivity, however, was obtained by applying the lactoperoxidase-catalysed iodination with ${ }^{125} \mathrm{I}$. Iodinated somatostatin-derivatives adsorbed onto an inorganic as well as an organic matrix; the percentage of non-specific binding was $14 \%$.

The radioimmunoassay was performed with an antiserum dilution of $1: 5000$. Displacement of labeled cyclic Tyr ${ }^{1}$. somatostatin by cold cyclic somatostatin was optimal with the use of $25-33.3 \mathrm{kBq} / 1$ and was in the range of $6 \mathrm{pmol} / 1-6 \mathrm{nmol} / \mathrm{l}$. Ocytocin, (lys)-vasopressin, (arg)-vasopressin, valinomycin, polymyxin, insulin, glucagon, human growth hormone (somatotropin), luteinizing hormone-releasing hormone (luliberin), and thyrotropin releasing hormone (thyroliberin) - each $10 \mu \mathrm{g} / 1$ - do not interfere with the radioimmunoassay. Linear somatostatin shows a weaker affinity to the antibody than cyclic somatostatin. Recovery of cyclic somatostatin added to human plasma, cerebrospinal fluid, pancreatic, hypothalamic, and pituitary tissue ranged from 77 to $84 \%$ when reextracted with acid acetone.

Using the method described, native cyclic somatostatin in human plasma could not be detected. We were able to detect $116 \pm 12 \mathrm{ng} / \mathrm{l}$ somatostatin in the acid acetone extract of freeze-dried cerebrospinal fluid from 4 healthy persons.

\section{Radioimmunoassay für zyklisches Somatostatin: Antikörpergewinnung, vergleichende Radiojod-Markierung und dose-response-Kurve}

Zusammenfassung: Eine radioimmunologische Methode zum Nachweis von cyclischem Somatostatin wird beschrieben. Synthetisches Somatostatin wurde zur Immunogendarstellung an Rinderserumalbumin und menschliches $\alpha$-Globulin mittels Glutaraldehyd gebunden. Sowohl mit Hapten-Rinder-Serumalbumin- als auch mit Hapten-Serum- $\alpha$-Globulin:Konjugat konnte Antiserum in Kaninchen erzeugt werden.

Da Somatostatin kein Tyrosin besitzt, das direkt jodiert werden könnte, wurde einerseits Tyr $^{1}$-Somatostatin nach verschiedener Methodik radiomarkiert. Andererseits wurde Somatostatin mit dem Bolton-Hunter-Reagenz markiert. Die Antigene wurden durch Adsorptionschromatographie über eine G-25-Sephadex Säule nachgereinigt. Die höchsten Ausbeuten wurden bei Jodierung von Tyr ${ }^{1}$-Somatostatin mit Hilfe von Chloramin-T, die höchste immunochemische Reaktivität dagegen durch Lactoperoxidase katalysierte Jodierung mit ${ }^{125} \mathrm{~J}$ erzielt. Jodierte SomatostatinDerivate adsorbieren leicht an anorganischer wie auch organischer Matrix. Der Prozentsatz der unspezifischen Bindung liegt bei $14 \%$.

Der Radioimmunoassay wurde mit 1:5000 verdünntem Antiserum durchgeführt. Verdrängung mit cyclischem Somatostatin ist bei Einsatz von $25-33 \mathrm{kBq} / 1$ optimal und liegt im Bereich von $6 \mathrm{pmol} / 1-6 \mathrm{nmol} / 1$. Ocytocin, (Lys)und (Arg):Vasopressin, Valinomycin, Polymyxin, Insulin, Glucagon, menschliches Wachstumshormon (Somatotropin), 
Luliberin und Thyroliberin - je $10 \mu \mathrm{g} / \mathrm{l}$ - stören die immunochemische Bindung von Somatostatin nicht. Lineares Somatostatin bewirkt eine schwache Verdrängung.

Mit der hier beschriebenen Methode ist die direkte Messung von cyclischem Somatostatin in menschlichem Serum bisher nicht möglich. Andererseits kann Somatostatin, das zu Serum oder anderem biologischen Material hinzugegeben wurde, mittels Extraktion zu 77-84\% wiedergefunden werden.

In cerebrospinalem Liquor 4 gesunder Personen wurden $116 \pm 12 \mathrm{ng} / 1$ cyclisches Somatostatin aus sauren Acetonextrakten der gefriergetrockneten Proben nachgewiesen.

\section{Introduction}

Somatostatin is a tetradecapeptide hormone which was recently isolated from sheep (1) and porcine hypothalami (2). The chemical synthesis of somatostatin in 1973 (1) provided the basis for the further analytical, physiological and pharmacological investigation of this hormone.

Somatostatin inhibits many endocrine and exocrine secretions as well as hormone production in neoplasms $(3,4,5)$. Endogenous somatostatin has been detected qualitatively by histoimmunochemical techniques in cerebral (6), pancreatic (7), and gastrointestinal tissue (8). The application of quantitative radioimmunological techniques has proved to be difficult, perhaps due to the very small concentrations of the hormone in organs and serum. In addition, the short biological half life (9) and occurrence of higher aggregations with somatostatin-like physiological effects $(2,10)$ represent additional complicating factors.

Therefore, it was one purpose of this work to develop a specific, sensitive radioimmunoassay for cyclic somatostatin. Since somatostatin must be derivatised before radiolabeling with ${ }^{125} \mathrm{I}$, various radioiodination procedures were performed and the immunochemical binding with antibodies was compared.

In this study we present results for the recovery and measurement of cyclic somatostatin in extracts of freeze-dried human cerebrospinal fluid.

\section{Materials and Methods}

The following materials were obtained from commercial sources: Cyclic somatostatin, linear somatostatin, and cyclic $\mathrm{Tyr}^{1}$-somatostatin (Serono, Freiburg); $\mathrm{Na}^{125}$ I and $\mathrm{Na}^{131} \mathrm{I}$ (AmershamBuchler, Braunschweig); Bolton-Hunter reagent (NEN, Dreieichenhain); human serum $\alpha$-globulin (Sigma, USA); bovine serum albumin (Serva, Heidelberg); Sephadex G-25 (Pharmacia, Frankfurt); Ultrogel AcA 54 (LKB, Berlin) Cellulose acetate foil $30 \times 100$ (Sartorius, Göttingen); all other chemicals were obtained from Merck (Darmstadt) or Boehringer (Mannheim) unless mentioned otherwise within the text. 8 adult rabbits, mixed-bred and with a minimum weight of $4 \mathrm{~kg}$, were obtained from Wulf (Königslutter).

\section{Buffers and solutions}

Elution buffer (buffer 1): $0.05-0.2 \mathrm{~mol} / \mathrm{l}$ ammonium acetate, $1 \mathrm{~g} / 1$ gelatine, $\mathrm{pH} 6.7$;

Dilution buffer (buffer 2): $0.01 \mathrm{~mol} / 1$ sodium phosphate, $0.14 \mathrm{~mol} / 1 \mathrm{NaCl}, 10 \mathrm{mmol} / 1$ EDTA, $1 \mathrm{~g} / 1$ gelatine, $\mathrm{pH}$ 7.5;
Acid acetone extraction solution (extract solution): $0.42 \mathrm{~mol} / 1$ acetic acid/acetone (volumes, $100 \mathrm{ml}+100 \mathrm{ml}$ ) Charcoal, Norit A'(Serva, Heidelberg), was coated with $15 \%$ dextran $T 70$ and diluted to $2.5 \mathrm{~g} / 1$ in $0,01 \mathrm{~mol} / 1$ sodium phosphate in $0.14 \mathrm{~mol} / 1 \mathrm{NaCl}, \mathrm{pH} 7.0$.

Glassware was methylsilanicated with dichlordimethylsilane $100 \mathrm{ml} / 1$ in benzene - by $1 \mathrm{~h}$ treatment at room temperature.

Immunogen synthesis

Somatostatin-human serum $\alpha$-globulin-and somatostatin-bovine serum albumin-conjugate were synthesized according to Habeeb \& Hiramoto (11). Cytochrome $\mathrm{c}$ was condensed as a model protein to synthetic cyclic somatostatin in the hollow fiber dialyse beaker b/HFD-1/20 (Serva, Heidelberg) and the products of the reaction were separated by Ultrogel AcA 54 gel filtration: $0.5 \mathrm{ml}$ aliquots of the reaction mixture were eluted at various reaction times with $0.05 \mathrm{~mol} / \mathrm{l}$ sodium phosphate, $\mathrm{pH} 7$, and the adsorption was measured at $280 \mathrm{~nm}$.

After $3 \mathrm{~h}$ the rest of the reaction mixture was dialysed for $30 \mathrm{~min}$ against a total of $300 \mathrm{ml}$ water at a throughput quota of $10 \mathrm{ml} /$ min. By this means, the hapten ligand complex was purified and then freeze-dried and stored at $8^{\circ} \mathrm{C}$.

\section{Antibodies}

8 rabbits were immunized by subcutaneous multiple injections of the following immunogenic suspension: One dose contained $1 \mathrm{ml}$ somatostatin-conjugate consisting of $120 \mu \mathrm{g}$ hapten (antigen), $2.5 \mathrm{mg}$ mycobacterium tuberculosis (dried cell walls from Robert-Koch-Institute, Berlin), $2 \cdot 10^{9}$ pertussis vaccine (Wellcome, England) in $0.5 \mathrm{ml} 0.14 \mathrm{~mol} / 1 \mathrm{NaCl}$ and $0.5 \mathrm{ml}$ complete Freund's adjuvant (Difco, USA). Booster injections were done at 2-3 week intervals with the immunogen suspension alone without additional mycobacteriae and pertussis bacteriae. Blood was drawn from the ear vein at 2-3 day intervals beginning 6 days after the second booster. The heparinized antiserum was frozen in $0.1 \mathrm{ml}$ batches and stored at $-20^{\circ} \mathrm{C}$.

\section{Radiolabeling}

Five different radioiodination techniques were carried out according to the following methods:

a) Chloramine-T oxidation of ${ }^{125} \mathrm{I}$ with somatostatin; Greenwood, Hunter \& Glover (12);

b) Acylation of somatostatin with N-succinimidyl-3-(4-hydroxy-[3-125 I]-phenyl)-proprionate; Bolton \& Hunter (13);

c) Chloramine-T oxidation of $\mathrm{Tyr}^{1}$-somatostatin; Greenwood, Hunter \& Glover (12);

d) Lactoperoxidase $/ \dot{\mathrm{H}}_{2} \mathrm{O}_{2}$ oxidation of ${ }^{125} \mathrm{I}_{\text {with }} \mathrm{Tyr}^{1}$-somatostatin; Marchalonis (14);

e) Lactoperoxidase/glucose oxidase-glucose oxidation of ${ }^{125}$ I with Tyr ${ }^{1}$-somatostatin; Mârshall \& Odell (16).

Standard labeling of $\mathrm{Tyr}^{1}$-somatostatin was performed according to the combined procedures d) and e): Cyclic Tyr ${ }^{1}$-somatostatin was iodinated with ${ }^{125}$ I which is oxidised by the lactoperoxidase/ $\mathrm{H}_{2} \mathrm{O}_{2}$ system (d). Excess ${ }^{125}$ I was removed by anion exchange resin (e). The experimental conditions for standard radioiodination assay are summarized in Table 1. 
Tab. 1. Radioiodination of $\mathrm{Tyr}^{1}{ }^{1}$-somatostatin by the lactoperoxidase- $\mathrm{H}_{2} \mathrm{O}_{2}$-system.

\begin{tabular}{|c|c|c|}
\hline $10 \mu \mathrm{l}=4 \mu \mathrm{g}$ & \multicolumn{2}{|l|}{$\begin{array}{l}\text { cyclic } \mathrm{Tyr}^{1} \text {-somatostatin } \\
\text { in } 1.2 \mathrm{mmol} / 1 \text { acetic acid }\end{array}$} \\
\hline $\begin{array}{l}20 \mu \mathrm{l} \\
10 \mu \mathrm{l}=37 \mathrm{MBg}(1 \mathrm{mCi})\end{array}$ & \multicolumn{2}{|c|}{$0.1 \mathrm{~mol} / 1 \mathrm{Na}$-phosphate, pH 7.5} \\
\hline $5 \mu 1=50 \mathrm{ng}$ & \multicolumn{2}{|c|}{$\begin{array}{l}\mathrm{Na}^{20 \mathrm{I}} \\
\text { lactoperoxidase (EC 1.11.1.7)* } \\
\text { diluted in } \mathrm{H}_{2} \mathrm{O}\end{array}$} \\
\hline $\begin{array}{l}\text { start: } \\
\text { reaction time: }\end{array}$ & \multicolumn{2}{|c|}{$2 \times 5 \mu 160 \mu \mathrm{mol} / 1 \mathrm{H}_{2} \mathrm{O}_{2}$} \\
\hline stop: & \multicolumn{2}{|c|}{ 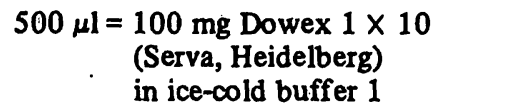 } \\
\hline \multicolumn{3}{|c|}{ * Suspension from Boehringer (Mannheim) } \\
\hline \multicolumn{3}{|c|}{ Tab. 2. Standard radioimmunoassay for cyclic somatostatin. } \\
\hline $\begin{array}{l}600-0 \mu l \\
100 \mu 1 \text { antiserum } 1 / \\
100 \mu 1\left[^{125} I\right] T^{1} r^{1}- \\
1-500 \mu l \text { somatostati } \\
\text { neutralized }\end{array}$ & $\begin{array}{l}1: 5000 \\
\text { natostatin, ca. } 33.3 \mathrm{~Bq} \\
6.14-3068 \mathrm{pmol} / 1 \text { or } \\
\text { mple extract }\end{array}$ & $\begin{array}{r}\text { buffer } 2 \\
\text { in buffer } 2 \\
\text { in buffer } 2 \\
\text { in buffer } 2\end{array}$ \\
\hline
\end{tabular}

The resin was separated by centrifugation and washed with $1 \mathrm{ml}$ of extract solution. The combined supernatants were used for further purification by column chromatography.

\section{Ad sorption chromatography}

For further purification of the radiolabeled antigen $0.8-1.6 \mathrm{ml}$ of the reaction mixture were separated at room temperature via a $1.5 \times 30 \mathrm{~cm}$ Sephadex G-25 column within $1.5 \mathrm{~h}$. For elution a $0.05-0.2 \mathrm{~mol} / \mathrm{l}$ buffer 1 was used. $2.3 \mathrm{ml}$ fractions were collected and aliquots were measured in the scintillation counter (Packard, USA).

\section{Cellulose acetate foil electrophoresis}

$5 \mu l$ of the reaction mixture were separated at $250 \mathrm{~V}$ and $2 \mathrm{~mA} /$ foil in $0.1 \mathrm{~mol} / 1$ barbitural buffer, $\mathrm{pH} 8.4$. Electrophoresis was allowed to proceed for $25 \mathrm{~min}$, with constant cooling with tap water. The foil was cut into $5 \mathrm{~mm}$ pieces and radioactivity was measured.

\section{Radioimmunoàssay and charcoal separation}

Methylsilanicated glass vials were used for antigen dilution and radioimmunoassay. Labeled somatostatin was diluted with buffer 2 to approximately $333 \mathrm{kBq} / \mathrm{l}$ immediately after $\mathrm{G}-25$ separation. Samples of cerebrospinal fluid or of other tissue were trieated with extract solution prior to the radioimmunoassay. All frozen and freeze-dried-serum- and tissue-suspensions were shaken with extract solution for $5 \mathrm{~min}$ at room temperature, neutralized with $0.1 \mathrm{~mol} / 1 \mathrm{NaOH}$, and diluted in buffer 2 .

A standard radio immunoassay was performed as summarized in Table 2. After an incubation period of $18 \mathrm{~h}$ at $2-4^{\circ} \mathrm{C}, 1 \mathrm{ml}$ charcoal suspension was added to each sample, placed in the ice-bath for $30 \mathrm{~min}$, centrifuged and washed with $1 \mathrm{ml} \mathrm{char-}$ coal-buffer.

Supernatant, washing solution, and charcoal were measured $(n=3-5)$ in the scintillation counteri, and the following values were calculated:

bound somatostatin $(B)=$ supernantant + washing solution free somatostatin (F) = charcoal total somatostatin $(T)$ = supernatant + washing solution + charcoạl.
The quantities of cyclic somatostatin in the unknown sample extracts were determined by comparison with the standard dose-response curve.

Extraction of cerebrospinal fluid samples

Approximately $10-20 \mathrm{mg}$ of freeze-dried cerebrospinal fluid from 4 healthy persons (diagnostic air myelography) were pooled and dissolved in $1 \mathrm{ml}$ distilled water and treated with the same volume of extract solution. After shaking for $5 \mathrm{~min}$ at room temperature, the sample was concentrated by evaporation under a stream of air, added to the dilution buffer, and the $\mathrm{pH}$ was recorrected with $0.1 \mathrm{~mol} / 1 \mathrm{NaOH}$. After this, the radioimmunoassay was performed under standard conditions.

\section{Results}

\section{Immunogen preparation}

In order to simplify the preparation of immunogen, the hapten ligand synthesis was carried out in the dialysis beaker, thus allowing the dialysis to follow immediately without decanting. A complete demineralisation was achieved after $30 \mathrm{~min}$. As shown in Figure 1, the glutaraldehyde coupling of cyclic somatostatin with proteoligand cytochrome $\mathrm{c}$ was monitored by ultrogel filtration of the reaction mixture. After $3 \mathrm{~h}$ reaction time, the somatostatin peak at $\mathrm{V}_{\mathrm{T}}$ had completely disappeared. The cytochrome c-somatostatin conjugate was eluted at $36 \mathrm{ml}$, and thus appeared slightly earlier than cytochrome c. $\mathrm{V}_{0}$ at $16 \mathrm{ml}$ showed a stronger absorption at $280 \mathrm{~nm}$ at the end of the reaction period. This may be due to the formation of a cytochrome c-cytochrome cconjugate.

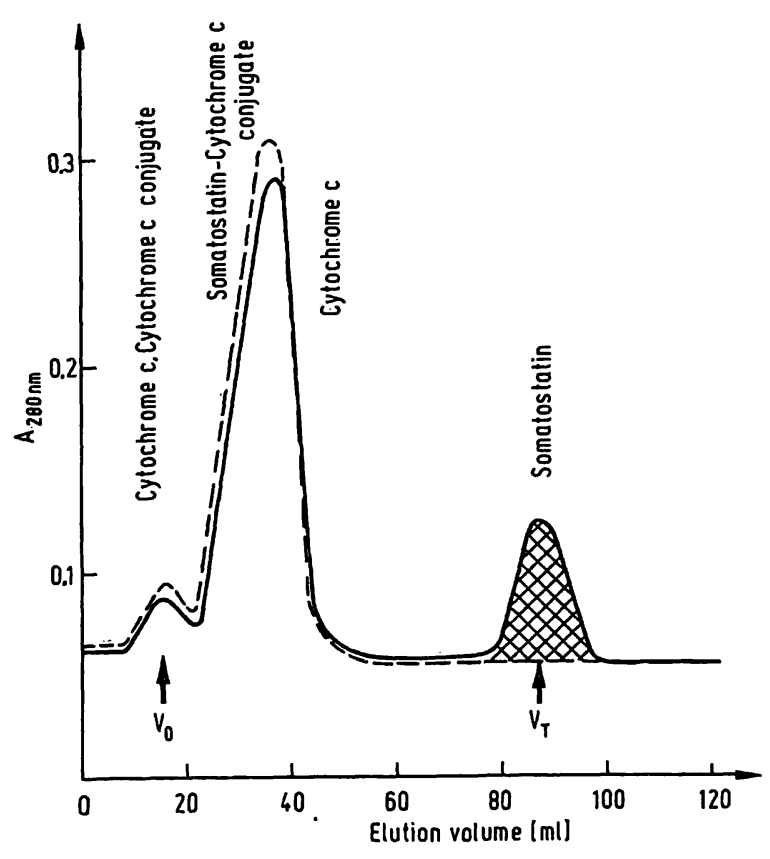

Fig. 1. Separation of cyclic somatostatin and cy tochrome c-somatostatin conjugate at the beginning - and at the end - - of the coupling reaction.

$1 \mathrm{ml}$ reaction mixture was separated with $0.05 \mathrm{~mol} / \mathrm{l}$ sodium phosphate at room temperature with an ultrogel AcA 54 column $(1.5 \times 30 \mathrm{~cm})$. Absorbance was measured at $280 \mathrm{~nm}$ (Uvicord II, LKB). 


\section{Characterisation of antisera}

One of 4 rabbits which were treated with human serum $\alpha$-globulin-immunogen $\left(F_{1}\right)$, and one out of another 4 rabbits treated with bovine serum albumin-immunogen $\left(\mathrm{IA}_{2}\right)$ developed acceptable antisera. When antiserum $\mathrm{IA}_{2}$ is diluted $1: 5000$ it binds approximately $50 \%$ of labeled antigen under standard conditions $\left(\mathrm{FA}_{1}\right.$ 1:2000).

The two rabbits with the high-titre antisera died after 27 $\left(\mathrm{FA}_{1}\right)$ and 13 weeks $\left(\mathrm{IA}_{2}\right)$. In contrast to the other rabbits with no antibodies, both had lost more than a quarter of their body weight and it is unclear whether they died due to the specific effect of anti-somatostatin or not.

In Figure 2 the time saturation curve of antiserum $\mathrm{IA}_{2}$ by iodinated $\mathrm{Tyr}^{1}$-somatostatin is presented. A plateau of saturation was reached after $18 \mathrm{~h}$ under standard conditions.

Excess $\mathrm{IA}_{2}$ binds maximally $82 \%$ of the labeled antigen. The binding portion of the "blank" sample without antiserum is approximately $14 \%(\mathrm{~B} / \mathrm{T})$.

Figure 3 shows a Scatchard plot. The association constant of the specific binding is calculated: $\mathrm{K}_{1}=$ $0.9 \cdot 10^{10} \mathrm{l} / \mathrm{mol}$. For the strongly $\mathrm{pH}$-dependent (nonspecific) binding the association constant is $\mathrm{K}_{2}=$ $3.2 \cdot 10^{5} \mathrm{l} / \mathrm{mol}$.

\section{Iodination of somatostatin} and $\mathrm{Tyr}^{1}$-somatostatin

Iodinated somatostatin-derivatives are strongly adsorbed to Sephadex G-25. This can be used for purification of radiolabeled somatostatin. The results of different radio-

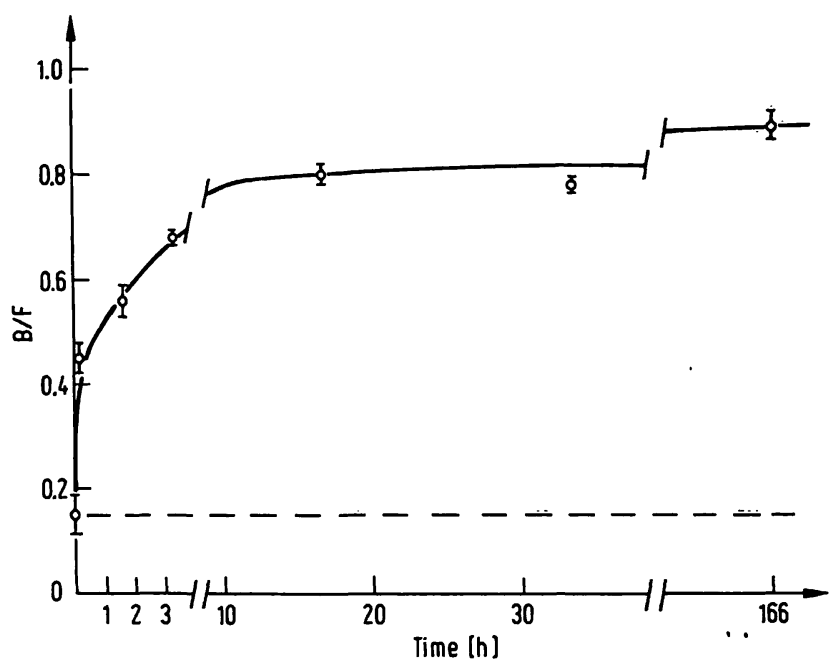

Fig. 2. Binding of $\left[{ }^{125} \mathrm{I}\right] \mathrm{Tyr}^{1}$-somatostatin with antiserum IA2 $(1: 5000)$ as a function of time. $0.8 \mathrm{ml}$ were taken from a $15 \mathrm{ml}$ standard assay after different incubation periods. After charcoal separation, radioactivity was measured and $B / F$ values were calculated $(n=3)$.

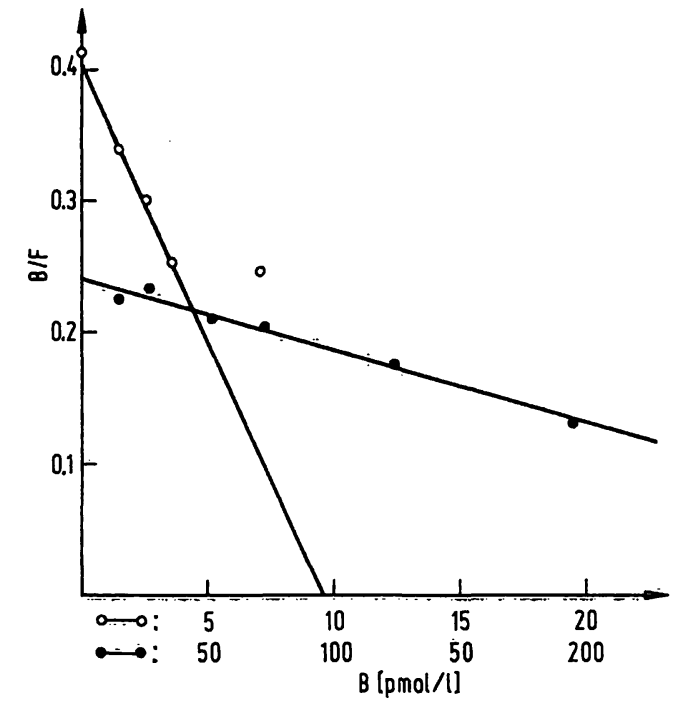

Fig. 3. Scatchard plot for the binding of [ $\left.{ }^{125} \mathrm{I}\right] \mathrm{T} \mathrm{yr}^{1}$-somatostatin with antibody IA2.

$2-1000 \mathrm{pmol} / 1$ of [ $\left.{ }^{125} \mathrm{I}\right] \mathrm{Tyr}^{1}$-somatostatin were incubated in a standard assay: Specific radioactivity $\equiv$ $18.5 \mathrm{MBq} / \mathrm{nmol}(0.5 \mathrm{mCi} / \mathrm{nmol}), \mathrm{K}_{1}=0.9 \cdot 10^{10} \mathrm{l} / \mathrm{mol}$ $\circ \longrightarrow \circ, \mathrm{K}_{2}=3.2 \cdot 10^{5} \mathrm{l} / \mathrm{mol} \bullet \longrightarrow$

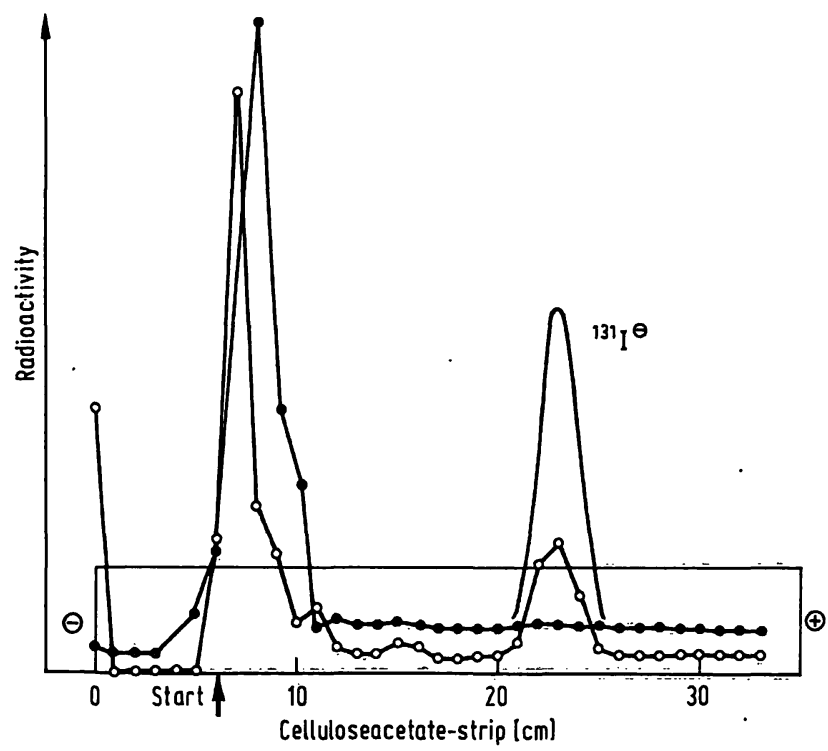

Fig. 4. Cellulose acetate foil electrophoresis of the reaction mixture: after radiolabeling of somatostatin $\bullet-\bullet$ according to Bolton \& Hunter (13), of $\mathrm{Tyr}^{1}$-somatostatin 0 - 0 according to this publication, and with $\mathrm{Na}^{131} \mathrm{I}-\mathrm{O}$.

$\mathrm{U}=250 \mathrm{~V}, \mathrm{I}=6 \mathrm{~mA}$, separation time $=25 \mathrm{~min}$ in $0.02 \mathrm{~mol} / \mathrm{l}$ barbital buffer, $\mathrm{pH}$ 8.7. Radioactivity was measured from $5 \mathrm{~mm}$ slices of the cellulose acetate foils.

iodination procedures can be compared by Sephadex G-25 adsorption-chromatography. In addition, the iodination was monitored by means of cellulose acetate foil electrophoreses (Fig. 4) and by CMC-ion exchange chromatography (10).

In Figures $5 \mathrm{a}-\mathrm{e}$ the elution curves of adsorption chromatography are summarized. Immunoreactive anti- 


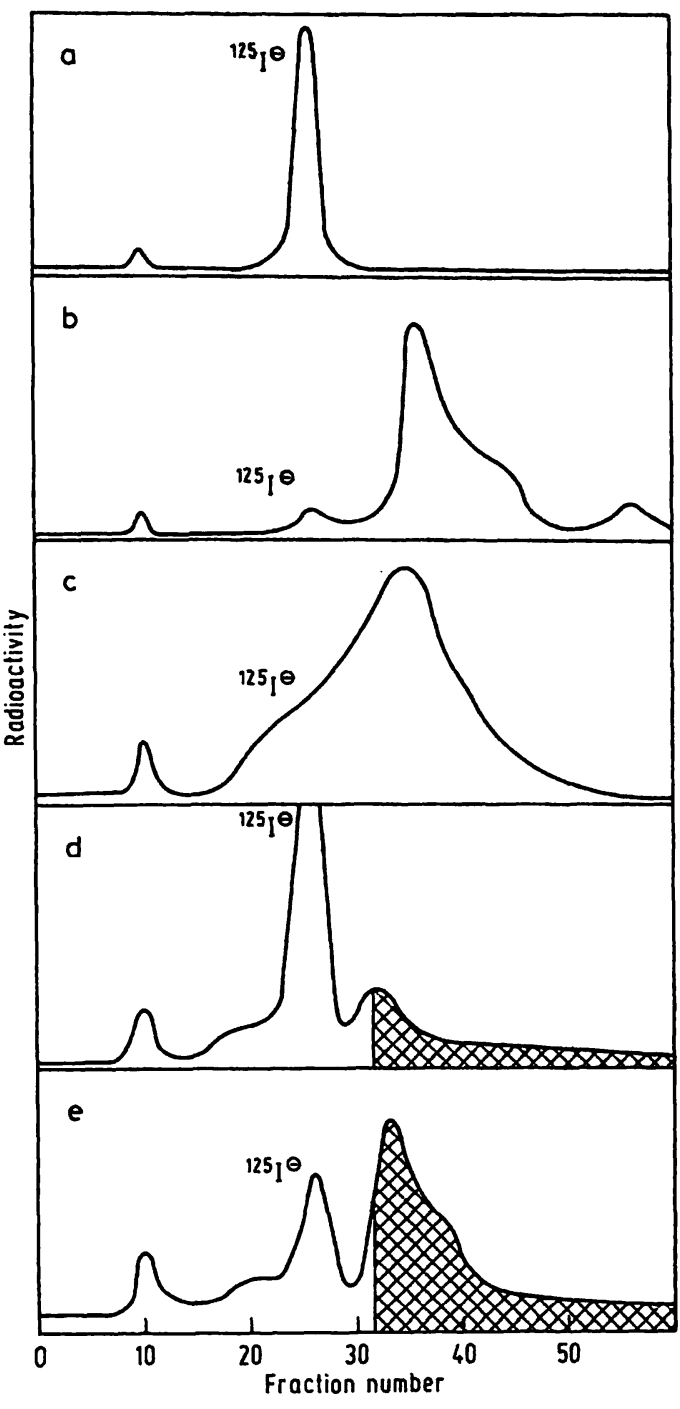

Fig. 5. Comparative adsorption chromatography after radiolabeling, with
a) ${ }^{125} \mathrm{I}^{-}$, chloramine-T, and somatostatin
b) N-succinimidyl-3-(4-hydroxy-[3-125I]phenyl)-pro- pionate, and somatostatin
c) ${ }^{125} \mathrm{I}^{-}$, chloramine-T, and $\mathrm{Tyr}^{1}$-somatostatin
d) ${ }^{125} \mathrm{I}^{-}$, lactoperoxidase $/ \mathrm{H}_{2} \mathrm{O}_{2}$, and $\mathrm{Tyr}^{1}$-somato- statin
e) $125_{I^{-}}$, lactoperoxidase/glucose oxidase, and $\mathrm{Tyr}^{1}$-somatostatin

The separation took place under standard conditions. In d) and e) the hatched area indicates immunochemically reactive somatostatin.

gen appears in the retarded peaks after fraction 30, unreacted ${ }^{125} \mathrm{I}$ in fraction 26 and higher aggregates in fraction 10 (dextran blue fraction).

Cyclic somatostatin was labeled using the method of Greenwood, Hunter \& Glover (12), but no radiolabeling could be demonstrated (Fig. 5 a). In contrast, when cyclic $\mathrm{Tyr}^{1}{ }^{1}$-somatostatin was labeled according to this method, nearly $100 \%$ of the eluted radioactivity was detected in the retarded fractions of the G-25 chromatography (Fig. 5c). However, no immunochemical reactivity could be demonstrated. No m-bisulfite was added as described in the original report of Greenwood, Hunter \& Glover (12) in order to avoid a reduction and/or polymerisation of the oxidized ring conformation of the peptides (16).

When the method of Bolton \& Hunter (13), using Nsuccinimidyl-3-(4-hydroxy-3-125 I-phenyl)-propionate, was applied, a yield of $80 \%$ in retarded peaks was measured (Fig. 5 b). Here too, however, no immunochemical reactions were detected with antibodies.

The results of the enzymatically catalysed iodination according to Marchalonis (14) and Marshall \& Odell (15) are shown in Figure $5 \mathrm{~d}$ and $5 \mathrm{e}$. The yields are lower than with direct iodine oxidation by chloramine-T. On the other hand a higher immunochemical reactivity was achieved.

In Figure 6 the immunochemical binding capacity of the individual fractions of a Sephadex G-25 separation is demonstrated (black bars). Based on the fact that all of the iodinated $\mathrm{Tyr}^{1}$-somatostatin appears in the retarded peak, it can be calculated that a specific radioactivity of $18.5 \mathrm{MBq} / \mathrm{nmol}(0.5 \mathrm{mCi} / \mathrm{nmol}) \mathrm{Tyr}^{1}$-somatostatin is obtained. This means that on the average each fourth labeled Tyr ${ }^{1}$-somatostatin molecule contains one radioactive ${ }^{125} \mathrm{I}$-atom. The yields vary greatly from one separation to the other in the range of $20-50 \%$. Reproducibility and the best yields could be achieved by pre-eluting and equilibrating of the Sephadex with gelatine and cold $\mathrm{I}-\mathrm{Tyr}^{1}{ }^{1}$-somatostatin.

For the determination of purity of the labeled antigen, and for the evaluation of non-specific binding, isoelectric focussing and disc-polyacrylamide gel electrophoresis were performed (18). Figure 7 a demonstrates the high

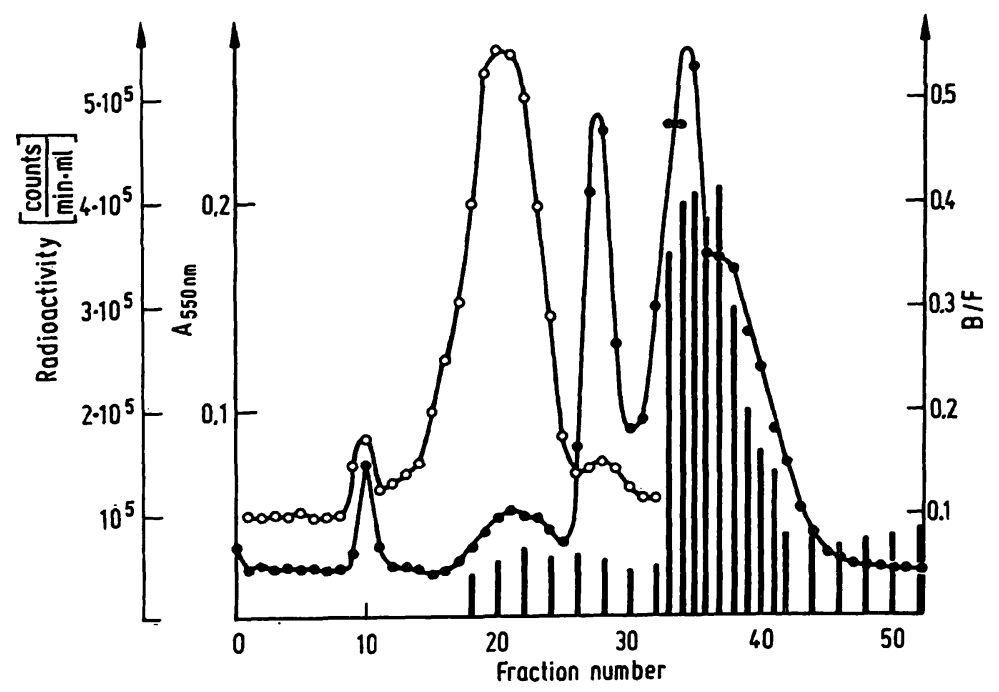

Fig. 6. Adsorption chromatography elution patterns of cyclic somatostatin and [ ${ }^{125}$ I] Tyr ${ }^{1}$-somatostatin, which was labeled under standard conditions.

Cold somatostatin was measured with the Folin-Ciocalteau phenol reagent (17) $0-0$ and labeled Tyr-somatostatin by its radioactivity $\bullet-\bullet$. The B/F values (black bars) were determined for each fraction with antiserum FA1 $(1: 2000)$ according to the standard method. Chromatographic conditions as in Figure 5. 

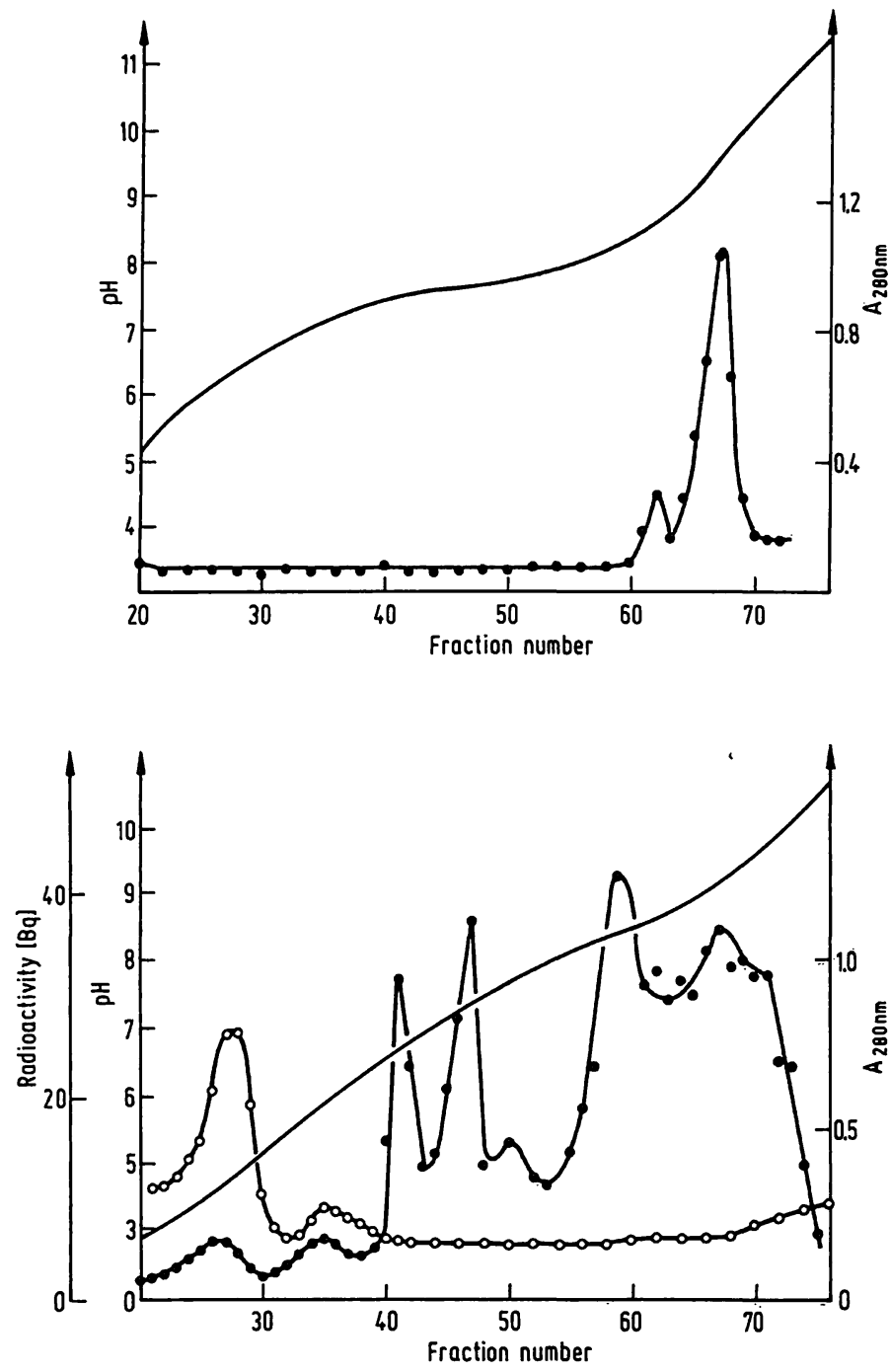

Fig. 7. Isoelectric focussing of

a) cyclic somatostatin Ampholine pH 3-10 (LKB, Sweden), incubation time $24 \mathrm{~h}$ at $10^{\circ} \mathrm{C}, \mathrm{U}=500-600 \mathrm{~V}$ $(0.8 \mathrm{~mA}), 2.5 \mathrm{ml}$ fractions; $1 \mathrm{mg}$ somatostatin was focussed and the fractions were measured at $280 \mathrm{~nm}$ $\bullet-\bullet$.

b) cyclic [ $\left.{ }^{125} \mathrm{I}\right] \mathrm{Tyr}^{1}$-somatostatin. Fraction 34 of the G-25 separation (Fig. 5) was focussed and radioactivity was measured $\bullet-2 \mathrm{mg}$ bovine serum albumin was also focussed and absorption was measured at $280 \mathrm{~nm} \circ-0$. Focussing conditions as in a).

purity of synthetic cold cyclic somatostatin and its main isoelectric point at 9.5 . Figure $7 \mathrm{~b}$ shows the inhomogeneity of the iodinated antigen in the alkaline $\mathrm{pH}$ range. In the isoelectric focussing as well as in the disc-polyacrylamide gel electrophoresis it could be demonstrated that radioactivity is bound to bovine serum albumin. The radioactivity in the $\mathrm{pH}$-range of the bovine serum albumin peaks contains $6.4 \%$ of the applied sample. The radioactivity in the neutral range possibly originates from spread iodinated lactoperoxidase.

\section{Recovery of [ $\left.{ }^{125} \mathrm{I}\right] \mathrm{Tyr}^{1}$-somatostatin}

When polystyrene tubes were used, $51 \%$ of the added radioactivity was adsorbed at the tube surface after two days incubation time under standard conditions. Therefore, methyl-silanicated glass tubes and pipettes were used for further work with small quantities of radioiodinated somatostatin. Thus, maximally $5 \%$ of the radioactivity was retained on the glass tubes as is shown in table 3 . The adsorption of $\left[{ }^{125} \mathrm{I}\right] \mathrm{Tyr}^{1}$-somatostatin on the tube surface and the portion of non-specific binding is demonstrated.

\section{Dose-response curve} and assay of serum and cerebrospinal fluid

Figure 8 demonstrates the standard (dose-response) curve obtained with antiserum, $\mathrm{IA}_{2}$, diluted 1:5000. There is specific competition in the range of $10-$ $1000 \mathrm{pg}$ per sample or $6.2 \mathrm{pmol} / 1-6.2 \mathrm{nmol} / 1 \mathrm{cyclic}$ somatostatin. The average maximal deviation (from the mean value $)$ is $\pm 7.4 \%(n=4-5)$. Cross-reactivity was observed for linear somatostatin (B/F: $0.8-0.7$ for $1-10 \mu \mathrm{g} / 1)$. No suppression was detectable after the addition of $1 \mu \mathrm{g} / \mathrm{l}$ of either ocytocin, (lys)-vasopressin (arg)-vasopressin, valinomycin, polymyxin, insulin, glucagon, human somatotropin, luliberin or thyroliberin.

When $1 \mu \mathrm{g} / 1$ somatostatin is added to charcoal-pretreated, boiled ( $5 \mathrm{~min}$ ) normal serum (Riacon) and reextracted with $1 \mathrm{ml}$ acid acetone, a dose response curve of the type shown in Figure 8 is obtained. Acetic acid acetone extracts from homogenates of pituitaries

Tab. 3. Adsorption of [ $\left.{ }^{125} \mathrm{I}\right] \mathrm{Tyr}^{1}$-somatostatin to the surface of plastic and glass tubes in the presence of different solvent systems. All solvent systems have a $\mathrm{pH}$ of 7.5 , incubation times $45 \mathrm{~h}$ at $2-4^{\circ} \mathrm{C}$. Total radioactivity $35 \mathrm{~Bq} / \mathrm{ml}$ and tube. For comparison $0.01 \mathrm{~mol} / 1 \mathrm{Na}-$ phosphate and $0.01 \mathrm{~mol} / 1$ imidazole $/ \mathrm{HCl}$ were used and $0.5 \mathrm{mmol} / \mathrm{l}$ phenylalanine (Phe) and $10 \mathrm{~g} / 1$ bóvine serum albumin (BSA) were added as protecting reagents. Glass tubes were methyl-silanicated as described in the text (Buffer 2 see page 5).

\begin{tabular}{llll}
\hline Solvent & $\begin{array}{l}\text { Tube } \\
\text { material }\end{array}$ & $\begin{array}{l}\text { Non- } \\
\text { specific } \\
\text { binding* }\end{array}$ & $\begin{array}{l}\text { Radioactivity } \\
\text { adsorption } \\
\text { on tube surface }\end{array}$
\end{tabular}

(\%)

\begin{tabular}{|c|c|c|c|}
\hline $\begin{array}{l}\text { Phosphate- } \\
\text { buffer } \\
+ \text { BSA } \\
+ \text { Phe }\end{array}$ & $\begin{array}{l}\text { Poly- } \\
\text { styrene }\end{array}$ & 12 & 51 \\
\hline $\begin{array}{l}\text { Imidazole- } \\
\text { buffer } \\
+\mathrm{BSA} \\
+\mathrm{Phe}\end{array}$ & $\begin{array}{l}\text { Poly- } \\
\text { styrene }\end{array}$ & 13 & 65 \\
\hline Buffer 2 & $\begin{array}{l}\text { Poly- } \\
\text { styrene }\end{array}$ & 10 & 51 \\
\hline Buffer 2 & Glass & 10 & 60 \\
\hline Buffer 2 & $\begin{array}{l}\text { methyl- } \\
\text { silanicated } \\
\text { glass }\end{array}$ & 14 & 5 \\
\hline
\end{tabular}

* radioactivity in the supernatant ạfter charcoal separätiôn. 


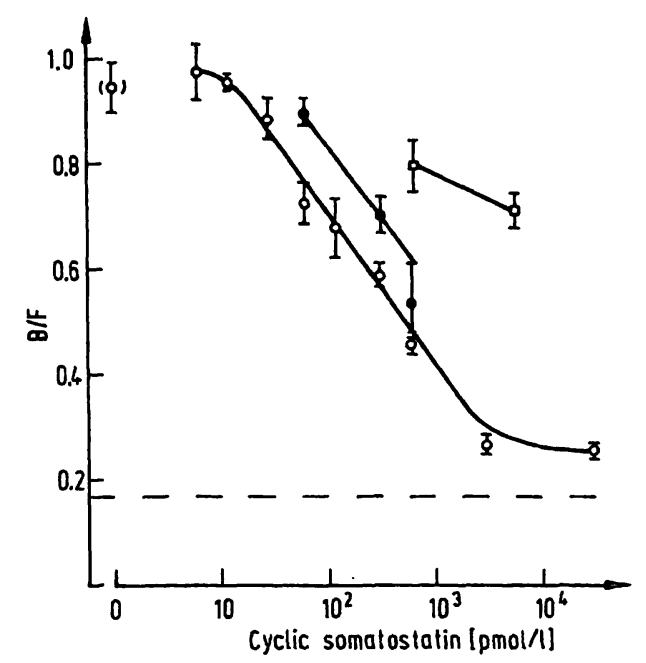

Fig. 8. Dose response curve of the radioimmunoassay for cyclic somatostatin.

Antiserum IA2 was used at a dilution of 1:5000. The concentrations of the added unlabeled somatostatin were plotted logarithmically on the abscissa. Bound (B) and free $(F)$ radioactivities were measured after charcoal treatment and the SEM $(n=4-5)$ were calculated for each sample. The displacement of $6.1 \mathrm{pmol} / \mathrm{l}-31 \mathrm{nmol} / 1$ cyclic somato statin $\circ-0$ (standard curve) is compared with the displacement of cyclic somatostatin $-\cdots$, which was added to normal serum (Riacon) and then reextracted. Cross reaction with linear somatostatin $\square-O$ is demonstrated. $B / F$ of the nonspecific binding is 0.17 and $B / F$ value of the sample lacking cold somatostatin is 0.95 .

and hypothalami of the rat and of chicken pancreas showed a similar dose response relation to that of normal serum samples.

An increase of B/F-values was observed when the volume of untreated aqueous cerebrospinal fluid-solution was raised from $0.04 \mathrm{ml}$ to $0.2 \mathrm{ml}$ per assay tube and $100 \mathrm{ng} / \mathrm{l}$ cyclic somatostatin were added to the cerebrospinal fluid-solution. This paradoxical effect could be abolished by extracting freezedried cerebrospinal fluid with acid acetone as described above.

Table 4 presents the $B / F$-values obtained when cerebrospinal fluid from four healthy persons was assayed. The corresponding somatostatin-concentrations are summarized. A somatostatin concentration of $116 \pm 12 \mathrm{ng} / 1 \mathrm{in}$ cerebrospinal fluid can be evaluated from the acid acetone extract of freeze-dried samples.

\section{Discussion}

This paper describes the development of specific antisera against cyclic somatostatin. Immunizations with somatostatin-bovine serum albumin as well as somatostatin-human șerum $\alpha$-globulin glutaraldehyde conjugate were successful. Although antiserum IA2, generated with somatostatin-bovine serum albumin-conjugate, shows a higher affinity for somatostatin, it cannot be concluded that bovine serum albumin is a better pro-
Tab. 4. Cyclic somatostatin in cerebrospinal fluid (CSF). Fresh, freeze-dried cerebrospinal fluid was obtained from 4 healthy persons during diagnostic air myelography.

Approximately $20 \mathrm{mg}$ of freeze-dried cerebrospinal fluid were dissolved in $1 \mathrm{ml}$ distilled $\mathrm{H}_{2} \mathrm{O}$ and an equal portion was treated with extract solution as described in the text.

Radioimmunoassay was performed under standard conditions. For B/F-values, deviations from the mean value $(n=3-4)$ were calculated.

\begin{tabular}{lllll}
\hline $\begin{array}{l}\text { cerebro- } \\
\text { spinal } \\
\text { fluid } \\
(\mathrm{ml})\end{array}$ & $\begin{array}{l}\text { somato- } \\
\text { statin } \\
\text { added } \\
(\mathrm{pg})\end{array}$ & Solvent & $\mathrm{B} / \mathrm{F}$ & $\begin{array}{l}\text { somatostatin } \\
\text { detected }\end{array}$ \\
\hline 0.04 & 20 & $\mathrm{H}_{2} \mathrm{O}$ & $41 \pm 2$ & $?$ \\
0.1 & 50 & $\mathrm{H}_{2} \mathrm{O}$ & $53 \pm 3$ & $?$ \\
0.2 & 100 & $\mathrm{H}_{2} \mathrm{O}$ & $92 \pm 12$ & $?$ \\
- & 100 & extract sol. & $48 \pm 3$ & 83 \\
0.1 & 100 & extract sol. & $45 \pm 8$ & 110 \\
1.0 & 100 & extract sol. & $34 \pm 4$ & 220 \\
- & - & extract sol. & $86 \pm 8$ & - \\
0.1 & - & extract sol. & $70 \pm 12$ & 15 \\
1.0 & - & extract sol. & $44 \pm 2$ & 116 \\
\hline
\end{tabular}

teoligand for immunization than human serum $\alpha$-globulin, because both rabbits (the "bovine serum albuminrabbit" and the "human serum $\alpha$-globulin-rabbit") died after too short a period of immunization.

Apart from the specificity, the (high) affinity of antibodies to antigen is a limiting factor for the sensitivity of a radioimmunoassay. Therefore, a Scatchard plot for IA2 was evaluated and the association constant was calculated. The high value of $\mathrm{K}_{1}\left(0.9 \cdot 10^{10} \mathrm{l} / \mathrm{mol}\right)$ indicates the sufficient affinity between IA 2 antibody and $\left[{ }^{125} \mathrm{I}\right] \mathrm{Tyr}^{1}$-somatostatin. According to Arimura et al. (10), the derivatisation with [ $\left.{ }^{125} \mathrm{I}\right] \mathrm{Tyr}$ on the lateral side of the peptide antigen is not disadvantageous for the immunospecificity, since with immunization at least one proteoligand is coupled at the same molecule side via $\mathrm{Ala}^{1}$.

Our results, however, demonstrate that iodinated $\mathrm{Tyr}^{1}{ }^{1}$. somatostatin shows high non-specific adsorptive reactivity, thus differing considerably from the adsorptive reactivity of the unlabeled antigen.

Iodinated somatostatin can be separated from the noniodinated somatostatin by means of Sephadex gel adsorption chromatography (Fig. 5). This effect has already been utilized for the purification of labeled ocytocin and vasopressin $(19,16)$. Strong adsorption of iodinated somatostatin to a solid phase can also be demonstrated with other chromatographic techniques, e. g. CMC-ion-exchange (10) and cellulose acetate foil electrophoresis (18).

Thus hydrophobization of the glassware and pre-elution of the chromatography columns (with I-Tyr ${ }^{1}$-somatostatin) was necessary for optimal recovery. 
Under such conditions radiolabeling with a final average yield of $39 \%$ was achieved. This value is higher than the yield of $14 \%$ reported by Miyachi et al. (20) who labeled luliberin with the lactoperoxidase $/ \mathrm{H}_{2} \mathrm{O}_{2}$-method, but our yield is significantly lower than the yield of $70-80 \%$ achieved by Arimura et al. (10). Because of the high specific radioactivity it can be assumed that in any case a portion of the labeled antigen is destroyed, and the derivatives finally interfere with the radioimmunoassay. The radioimmunoassay described here has confirmed many of the findings previously reported by Arimura et al. (10). In particular, the inhibition of the $\left[{ }^{125} \mathrm{I}\right] \mathrm{Tyr}^{1}$-somatostatin binding was observed after the addition of charcoal-washed serum to the radioimmunoassay. Arimura et al. (10) have suggested that inhibition by somatostatin-like substances or non-specific reactions with plasma protein may be responsible for the insufficient sensitivity.

The fact that no somatostatin could be detected in normal serum may be due to the insufficient sensitivity. As is shown in Figure 8, the dose related suppression with synthetic cyclic somatostatin is in a range similar to the dose response correlation which was observed by $A r i-$ mura et al. (10). McIntosh et al. (21) more recently reported a sensitivity of $2 \mathrm{ng} / \mathrm{l}$ of their radioimmunoassay for somatostatin. The non-specific reactivity of iodinated $\mathrm{Tyr}^{1}$-somatostatin seems to be another interfering factor as indicated by the high value of $\mathrm{K}_{2}$ $\left(3.2 \cdot 10^{5} \mathrm{l} / \mathrm{mol}\right)$. Furthermore, experiments with disc-polyacrylamide gel electrophoresis (18) and isoelectric focussing (Fig. 7) show that multivalent reactivity with protein is possible. The high value of the blank, $14 \%(\mathrm{~B} / \mathrm{T})$, indicates the same phenomenon.

The "hairpin loop" structures suggested for cyclic somatostatin by Holladay \& Puett (22) offer an explanation of the multivalent reactivity of cyclic somatostatin and its cyclic derivatives: One side with the aromatic residues of the straightened ring-peptide reacts hydrophobically, and the other side with hydroxy and acidic functions reacts hydrophilically. The multivalent reactivity seems to be increased, when $\mathrm{Tyr}^{1}$-somatostatin is iodinated or native somatostatin is coupled with $p$-hydroxy-[ $\left[{ }^{125} \mathrm{I}\right]$ phenyl-propionate. With the latter labeling method (13), however, the absence of specific binding with antibodies is apparently due to a derivatisation at the free primary lysine amino groups of somatostatin.

\section{References}

1. Brazeau, P., Vale, W., Burgus, R., Ling, N., Butcher, M., Rivier, J. \& Guillemin, R. (1973), Science 179, 77-79.

2. Schally, A. V., Dupont, A., Arimura, A., Redding, T. W., Nishi, N., Linthicum, G. L. \& Schlesinger, D. H. (1976), Biochemistry 15, 509-514.

3. Hall, R., Besser, G. M., Schally, A. V., Coy, D. H., Evered, D., Goldie, D. J., Kastin, A. J., McNeilly, A. S., Mortimer,
Since somatostatin has been located at ventricular nerve endings by histoimmunochemical techniques (6) and elevated somatostatin concentrations in cerebrospinal fluid of patients with spinal and brain disease have been reported (23), attempts were made to determine cyclic somatostatin in cerebrospinal fluid using the techniques described here.

A similar effect to that observed with human serum, i. e. initial suppression but no dose-response relationship, was also observed when fresh human cerebrospinal fluid was added to the radioimmunoassay.

The opposite effect, a "paradoxical suppression" was measured when synthetic cyclic somatostatin was added to the untreated cerebrospinal fluid solutions, which were then added in increasing volumes to the assay. An interpretation of this unexpected increase of $B / F$-values is possibly given by the fact that under these experimental conditions a macromolecular carrier, soluble in cerebrospinal fluid, is present in higher concentrations and binds somatostatin in an exponential manner. Moreover, a higher somatostatin-aggregation (2), induced by somatostatin itself, is possible. This would yield an apparent lower concentration of monomeric cold antigen in the radioimmunoassay.

Applying the described acidic acetone extraction procedure, a dose related response can be achieved. By comparison with the standard curve (Fig. 8), we determined $116 \pm 12 \mathrm{ng} / \mathrm{l}$ somatostatin in cerebrospinal fluid of four healthy persons. This value is more than two and a half time higher than that determined for normal subjects by Patel, Rao \& Reichlin (23) $(42.5 \pm 5.2 \mathrm{ng} / \mathrm{l})$.

This disagreement seems understandable considering the variation in sampling procedures, extraction techniques and assay conditions used.

\section{Acknowledgements}

The authors wish to thank Miss Renate Hintze for technical assistance and Dr. Eva Diel, Institut für Lebensmittelchemie, TU Berlin, for performing isoelectric focussing analyses. We are grateful to Dr. A. Arimura, Tulane University School of Medicine, New Orleans, Louisiana 70112, for a gift of antisomatostatin serum.

This work was supported by the Deutsche Forschungsgemeinschaft (Qu 22/6).
C. H., Phenekos, C., Turnbridge, W. M. G. \& Weightman, D. (1973), Lancet II , 581-584.

4. Alberti, K. G. M. M., Christensen, N. J., Christensen, S. E. Hansen, A. P., Iversen, J., Lundbaek, K̇., Seyer-Hansen, K. \& Qrskov, H. (1973), Lancet $I I, 1299-1301$.

5. Oliver, J. R. \& Wagle, S. R. (1975), Biochem. Biophys. Res. Commun. 62, 772-777. 
6. Dubé, D., Leclerc, R., Pelletier, G., Arimura, A. \& Schally, A. (1975), Cell Tiss. Res. 161, 385-392.

7. Orci, L., Baetens, D., Dubois, M. P. \& Rufener, C. (1975), Horm. Metab. Res. 7, 400-402.

8. Raptis, S., Dollinger, H. C., Berger, L. v., Schlegel, W., Schröder, K. E. \& Pfeiffer, E. F. (1975), Digestion 13, $15-26$.

9. Brazeau, P., Rivier, J., Vale, W. \& Guillemin, R. (1974), Endocrinology 94, 184-187.

10. Arimura, A., Sato, H., Coy, D. H. \& Schally, A. V. (1975), Proc. Soc. Exp. Biol. Med. 148, 784-789.

11. Habeeb, A. F. S. A. \& Hiramoto, R. (1968), Biochim. Biophys. Acta 126, 16-26.

12. Greenwood, F. C., Hunter, W. M. \& Glover, J. S. (1963), Biochem. J. 39, 114-123.

13. Bolton, A. E. \& Hunter, W. M. (1973), Biochem. J. 133, 529-539.

14. Marchalonis, J. (1969), Biochem. J. 113, 299-305.

15. Marshall, J. C. \& Odell, W. D. (1975, Proc. Soc. Exp. Biol. Med. 149, 351-355.
16. Husain, M. K., Fernando, N., Shapiro, M., Kagan, A. \& Glick, S. M. (1973), J. Clin. Endocrinol. Metab. 37, 616625.

17. Lowry, O. H., Rosenbrough, N. J., Farr, A. L. \& Randall (1951), J. Biol. Chem. 193, 265-275.

18. Diel, F., Schneider, E. \& Quabbe, H. J. (1976), $2^{\text {nd }}$ European Congress on Clinical Chemistry, Prague, Abstract 27.

19. Chard, T., Kitau, M. J. \& Landon, J. (1970), J. Endocrinol. 46, 269-278.

20. Miyachi, Y., Chrambach, A., Mecklenburg, R. \& Lipsett, M. B. (1972), Serono Foundation Conference, Acapulco, 92-97.

21. McIntosh, C., Arnold, R., Köbberling, I. \& Creutzfeld, W. (1976), Diabetologia, in press.

22. Holladay, L. A. \& Puett, D. (1976), Proc. Nat. Acad. Sci. USA 73, 1199-1202.

23. Patel, Y. C., Rao, K. \& Reichlin, S. (1975), Clin. Res., 389 A, Abstract.
Dr. F. Diel

Med. Klin. Abt. Endokrinologie

Klinikum Steglitz

Freie Universität Berlin

Hindenburgdamm 30

D-1000 Berlin 45 
